\title{
Renovation and Rehabilitation Strategies for Worn-Out Texture of Ab-Anbar-No District in Sari Using SWOT Technique
}

\author{
Abbas Alipour Nakhi' ${ }^{1}$ Niloufar Ahmari ${ }^{2}$, Saeid Rezaei ${ }^{2 *}$ \\ ${ }^{1}$ Department of Economic, Social and Extension, Mazandaran Agricultural and Natural Resources Research and \\ Education Center, Sari, Iran \\ ${ }^{2}$ Department of Architecture Engineering, Sariyan Higher Education institute, Sari, Iran \\ Email: a.alipour@areo.ir, ahmari_niloo@yahoo.com, "saeidrezaei70@Gmail.com
}

Received 23 February 2016; accepted 18 April 2016; published 21 April 2016

Copyright (C) 2016 by authors and Scientific Research Publishing Inc.

This work is licensed under the Creative Commons Attribution International License (CC BY).

http://creativecommons.org/licenses/by/4.0/

(c) (i) Open Access

\begin{abstract}
Along with the growth and expansion of cities during the time, several parts of them have depreciated and they require repairing and inspection. Damaged places and repairing them are a problem that is significant and liable of each period has been looking for excogitation and resolving problems according to the existing circumstances. However, expressed concern that it is still a problem, is worn texture, which is extending fast in all cities of the world, particularly in developing countries, and this problem has gripped cities and authorities. In spite of all weaknesses and deficiency, since the majority of worn-out tissues have significant cultural, social and economic values which give identity to the cities, so paying attention to these areas and how to intervene in them is very important. The purpose of this paper is to study and consider ways of rehabilitation and renovation of the old texture of Ab-Anbar-No district in Sari, which it has been done using analytical-descriptive method. In this study, the needed information has been collected by observation, providing necessary map, library research and rehabilitation and reconstruction strategies have gained by SWOT model for analysis and internal factors (strengths and weaknesses) and external factors (threats and opportunities) of this tissue have been considered comprehensively. The results of this study show that strategies for rehabilitation and renovation of Ab-Anbar-No district are one part of the guidance, control and planning system of urban rehabilitation and modernization, as a guide for decision-making. The considered limitation of weakness and strengths in physical, environmental and functional fields have a high vulnerability and also have optimization opportunities in the economic, social and legal-administrative fields in order to take advantages for reaching perfection.
\end{abstract}

*Corresponding author.

How to cite this paper: Nakhi, A.A., Ahmari, N. and Rezaei, S. (2016) Renovation and Rehabilitation Strategies for Worn-Out Texture of Ab-Anbar-No District in Sari Using SWOT Technique. Open Journal of Geology, 6, 270-283.

http://dx.doi.org/10.4236/ojg.2016.64024 


\section{Keywords}

\section{Rehabilitation, Renovation, Worn-Out Texture, Ab-Anbar-No District, SOWT}

\section{Introduction}

City is an intertwined structure that many institutions and individuals are involved in the formation of social life and its facade. By reviewing cities expansion and civic and social interaction, they have getting changes, evolution, growth, and development over the time as well as other human artifact. This development is a dynamic and continuous process which during it the city physical limits and physical spaces change in vertical and horizontal directions as to increasing quantitative and qualitative terms and if this trend is rapid and unplanned, physical formation of urban spaces will not be appropriate. Consequently, urban system will face serious problems [1]. Iran cities due to the increasing population, are physically extending continuously that are often horizontally and occupy extensive their surrounding areas. During the time, and ownership changing in urban central texture, they will suffer physical quality and get exhaustion. The worn areas in cities are four types as follows: 1) textures with a historical and urban heritage; 2) urban areas (non-historical); 3) fringe areas (informal settlements); 4) inefficient tissues [2]. These cities are need to their worn tissues to survive. Generally, the belief to improve the environment is one of the sources of the special idea for urban planning and perhaps the most important ideology that is consistent [3].

(Urban historical texture) refers to those legal urban areas that because of physical worn, lack of suitable availability for cavalry, facilities, services and urban infrastructure are vulnerable and they have low economic, environmental and local values [4].

The term renovation and rehabilitation generally means a change of urban environment in order to organize urban problems [5]. Renovation and rehabilitation of urban historical contexts has always been important not only to protect the historic towns and cultural monuments, but also to respond to urban needs and caused repairing old damage and damage on building and new operation adapted by needs of life [6]. Their purpose is to improve the quality of life in worn tissue [7]. On the other hand, the different politics of modernization in different countries and epochs has had effective worthy results in development of urban renewal [8]. Thus, a first step in renovation of worn-out texture is their identification and prioritization to intervene and determine the type of intervention and investment. In this texture, lack of proper and correct identification and prioritization of this texture will result inefficient modernization programs and wasting resources and capital, and the subsequent expansion of the wear in the urban fabric [9].

Sari Ab-Anbar-No district is made of appropriate grading in the form of volumes free on the non-geometric space like other urban historical texture, as the private spaces around them are moving around the spaces and create a continuous space that makes it possible for texture to utilize of green and out-door spaces. However, new interventions cause confusion in the past organization. Even though surrounding parts of Ab-Anbar-No passing is still generally retaining their quality, but new construction has created difficulties in that area. Most estate parts are for small components belonging to the different people and most of the residential and commercial estate parts are less than 200 square meters, or between 200 to 250 square meters and usually are private estate [10]. So, this research has modified to review and assess the policies of renovation and rehabilitation urban tissue with an emphasis on Sari city. In this record, the research framework is in order to respond to the questions follows:

- How much of capacity and capabilities of a.a.no storage areas had been appropriate for rehabilitation and renovation to restore and create vitality to the historic fabric?

- How much of the current state of Ab-Anbar-No district had faced with constrains and impasses for rehabilitation and renovation to restore and create vitality to the historic fabric?

Considered assumptions are on the basis to achieve a pattern of create urban vibrant spaces in the old texture and furthermore vitality factors, conditions of environmental configuration must be in good conditions.

\section{The Importance and Necessity of Research}

The need for restoration and repair of old and valuable historical texture has considered stimulating physical, 
social, and economic texture and the old area. Parts of the city lose their former growth and, the texture gradually discharged from the indigenous population because of population growth and uncontrolled urban development, and lack of services to older tissue, and replaced with the immigrant population it, over the time. one of issues that cause attention to problems related to old and worn-out texture, is the use of inexpensive and outdated materials in most of old buildings of the tissue, which is a serious threat to the safety of residents at the of events of natural disasters. This problem doubled up the necessity of reformation and modernization and equipping worn settlements [11].

disarrangement between scale and physical capacity of old texture with today pattern is most important reason of evacuation, and lack of proper access to cavalry within the texture and the subsequent problems of service, instability and the use of inappropriate materials in new construction and the poor quality of infrastructure facilities and installation are important factor. So if the orientation and direction of the worn-out tissue followed by interventions without the program. These tissues have increased problems day by day and they become turbulent places. So deliberation is essential for these problems.

\section{Research Objectives}

Strategic planning is one of the pillars of redevelopment and improvement programs. Proper comprehension and precise use of planning and strategic tool for development of strategic planning makes it possible to access the redevelopment and improvement programs [12]. So, in this article we have tried to develop and improved AbAnbar-No districts again using the proper and precise tools and updated programs is considered.

\section{What Is the Necessity of Research and the Statement of the Problem as Objectives of This Article Are Following?}

1) Rehabilitation and vitality in old and historical texture.

2) Facilitating accessibility as the most important factor in the dynamics and services to old textures.

3) Improving performance with respect to the living body.

4) The physical rehabilitation with people coordination.

In addition, it should be noted that this district Ab-Anbar-No, include its accessory spaces and valuable buildings, is the part of old the city center. That any construction changes in it demands its own legitimacy.

\section{Research Method}

The purpose of this research, is applied-studious and its essence and method is studious analytical-descriptive. In this descriptive-analytical research, the current status of the texture is studied for understanding the subject. The methods used to collect data, are obtained through library research and use of documents and field data, preparing a questionnaire to record information. The statistic population of study was university professors and experts and scholars in architecture which uses a questionnaire of 30 samples were direct Question-ing.

By documentary and by visiting professors of architecture and gaining information, a questionnaire was developed that in each of the specified internal and external factors in the questionnaire get a coefficient (from 1: Very low to 5 Very high ) and so we ranked any of the factors or parameters from 1 to 5 based on their value in terms of architectural experts rating and we defined their coefficient $(\mathrm{Rj})$ and then by accomplishing the questionnaires by the subjects target population of 30 people, parts of defects was eliminated. The SWOT technique is used to provide practical solutions. In this method of valuation and scoring the internal strengths and weaknesses and the opportunities and external threats, suitable strategies have been proposed for renovation and modernization [13].

\section{Introduction of Research Limitation}

Ab-Anbar-No district was one of five old Sari district. This district is located in the central area of the Sari city. This area is limited by the Qaran streets from the south, Farhang street from east and 18 D from North and Enqelab street from West, with the pottage of 96/18 hectare, housed a population with 2271 people, with gross density equal 120 people. New residential buildings and public face of the field in the form of old houses. Access to this area through narrow passages with low quality asphalt, is provided. This area, as well as other areas of the city's area is a residential area with commercial applications and business services can be seen at the 
urban scale. Part of the fabric of this area to preserve its ancient skeletal system, the value of the Iranian city.

The old residents of this area are shopkeepers, all of the residents are mostly sari. However, about 5 percent of current residents and residents of surrounding villages constitute the workers and employees and shopkeepers are busy with average income levels. Most dwellings are living in their residential property owners, but tenants are also present in units of 2 or more floors, about 30 percent of residents have formed tissue, see Picture 1 [14].

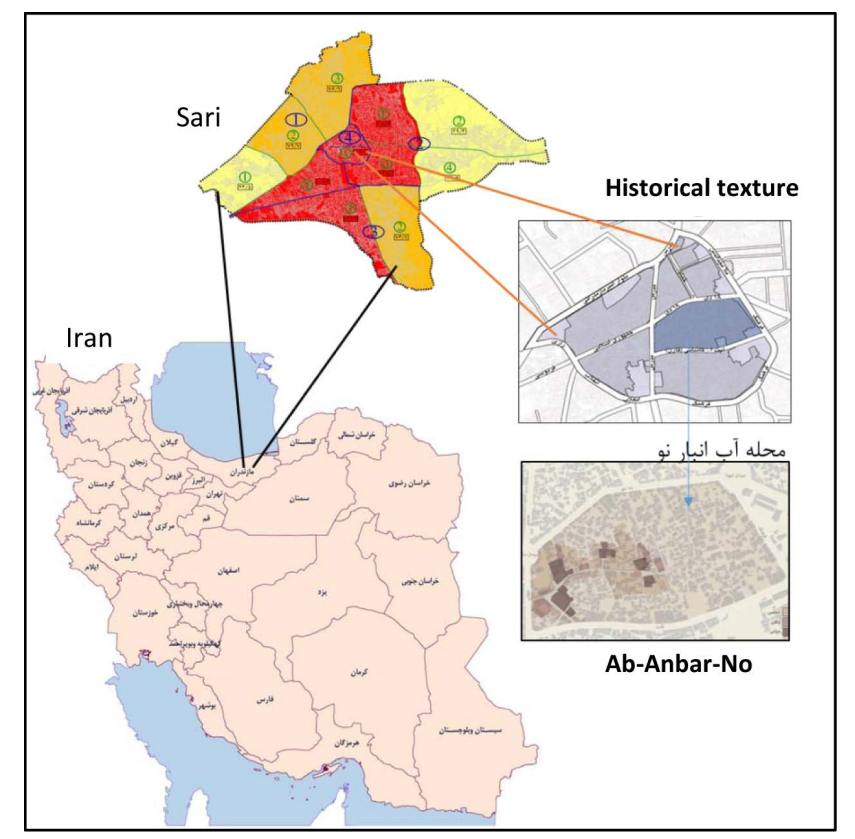

Picture 1. Ab-Anbar-No limitation in sari [14].

\section{Study of Effects of Rehabilitation and Renovation Projects Using the SWOT Matrix}

SWOT model consists of the first four words of English letters with the Persian Equivalent strengths, weaknesses, opportunities, and threats. This equivalent (strengths, weaknesses, opportunities and threats) is the best strategy for the planning process [15]. And is one of efficient models of strategic management [16]. This technique is a support tool for decision-making that are commonly used to systematically analyze the internal and external environment of organization or city. By defining strengths and weaknesses and the opportunities and threats, the organization or the city can adopt strategies to reinforce the strengths and eliminate the weaknesses and can use the opportunities to counter threats [17]. In this study the characteristics of social, economic, physical-performance, environmental-communicative and administration of ancient texture of Ab-Anbar-No district in Sari have been analyzed using SOWT techniques based on quantitative and qualitative data that to lead organize and future planning strategies in the direction of the strategically strategies objectives of the revive the old structure of the Sari city.

The SWOT method is a qualitative approach. However, in this study it have been tried to quantify the method to achieve stronger results and have been used "Delphi technique" to utilize experts [18]. This technique uses a special table that enable regular and systematic classification of internal and external environment, and using elements of this table, study provides realistic and proper strategies in direction of city development [19].

\subsection{Internal and External Strategic Assessment}

Internal and external strategic evaluation causes decision makers and assessment planners to apply the quantitative stage in the development trend of strategic objectives and strategies [20]. The analysis that is done about the relative importance of internal and external factors of Ab-Anbar-No district in Sari, makes it possible that provide different strategic objectives and strategies by effective manner, see Table 1, Table 2. 
Table 1. The internal factors of evaluation matrix (strengths and weaknesses).

\begin{tabular}{|c|c|c|c|c|c|c|c|c|c|c|c|c|c|}
\hline \multirow[b]{2}{*}{ 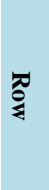 } & \multirow[b]{2}{*}{ Strengths } & \multicolumn{5}{|c|}{ Frequency } & \multirow[b]{2}{*}{ స్ర } & \multirow[b]{2}{*}{ Weaknesses } & \multicolumn{5}{|c|}{ Frequency } \\
\hline & & 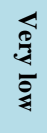 & $\sum_{\xi}^{5}$ & 衣 & 睘: & 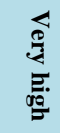 & & & $\frac{\substack{g \\
\frac{g}{2}}}{\xi}$ & $\sum_{\xi}^{5}$ & 文 & 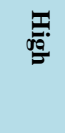 & 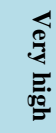 \\
\hline 1 & $\begin{array}{l}\text { Residence in the district and not } \\
\text { being abandoned the old texture }\end{array}$ & 0 & 5 & 10 & 7 & 8 & 1 & $\begin{array}{l}\text { Poor performance of Social, economic } \\
\text { and housing In the district (is not vitality } \\
\text { texture) }\end{array}$ & 0 & 5 & 10 & 7 & 8 \\
\hline 2 & $\begin{array}{l}\text { Long living background of some } \\
\text { families with high social status and } \\
\text { neighborhood communication }\end{array}$ & 0 & 1 & 9 & 12 & 8 & 2 & $\begin{array}{l}\text { Residents tend to aggregate Parts and } \\
\text { urbanization }\end{array}$ & 0 & 1 & 9 & 12 & 8 \\
\hline 3 & $\begin{array}{l}\text { Traditional structure of district and } \\
\text { credit Elders to residents }\end{array}$ & 0 & 0 & 9 & 9 & 12 & 3 & $\begin{array}{l}\text { Reducing the rate of population in the } \\
\text { texture in compared total city's } \\
\text { population }\end{array}$ & 0 & 0 & 9 & 9 & 12 \\
\hline 4 & $\begin{array}{l}\text { The high price of land in the } \\
\text { tissue (Investment incentives. is } \\
30 \% \text { for rental and the rest are } \\
\text { landlord) }\end{array}$ & 2 & 3 & 12 & 11 & 2 & 4 & Lack of proper cultural places on district & 2 & 3 & 12 & 11 & 2 \\
\hline 5 & $\begin{array}{l}\text { Existence of commercial and } \\
\text { administrative units On surrounding } \\
\text { streets, Residence supportive }\end{array}$ & 1 & 4 & 10 & 10 & 5 & 5 & $\begin{array}{l}\text { Decreasing security because of lack of } \\
\text { lighting particularly at nights }\end{array}$ & 1 & 4 & 10 & 10 & 5 \\
\hline 6 & $\begin{array}{l}\text { Meet the needs of area residents } \\
\text { through The glazed area (because of } \\
\text { Closing to downtown) }\end{array}$ & 0 & 5 & 9 & 11 & 5 & 6 & $\begin{array}{l}\text { Defect of proper activity concerning } \\
\text { tourism }\end{array}$ & 0 & 5 & 9 & 11 & 5 \\
\hline 7 & $\begin{array}{l}\text { Existence of valuable architecture } \\
\text { buildings }\end{array}$ & 0 & 1 & 4 & 4 & 21 & 7 & $\begin{array}{l}\text { The relative stagnation of business } \\
\text { activity in Some parts of the tissue }\end{array}$ & 0 & 1 & 4 & 4 & 21 \\
\hline 8 & $\begin{array}{l}\text { Location of the district on historical } \\
\text { texture and downtown (closing } \\
\text { district to masjed jaame, bazaar and } \\
\text { saat squar) }\end{array}$ & 0 & 0 & 2 & 13 & 15 & 8 & $\begin{array}{l}\text { Lack of arrangement between old } \\
\text { buildings face and news one }\end{array}$ & 0 & 0 & 2 & 13 & 5 \\
\hline 9 & $\begin{array}{l}\text { Functional value as religious, } \\
\text { cultural center, because of Hasina } \\
\text { and bazaar and business centers } \\
\text { on texture }\end{array}$ & 0 & 1 & 3 & 17 & 9 & 9 & $\begin{array}{l}\text { Difficulty of renovation and building } \\
\text { activity because of meandrous alleys }\end{array}$ & 0 & 1 & 3 & 17 & 9 \\
\hline 10 & $\begin{array}{l}\text { Existence of cullis for gathering } \\
\text { Surface water in some passages }\end{array}$ & 3 & 6 & 13 & 4 & 4 & 10 & $\begin{array}{l}\text { Lack of cultural complexes, Art centers } \\
\text { and libraries public centers, conference } \\
\text { and Theater halls, cultural institutions } \\
\text { and Etc. }\end{array}$ & 3 & 6 & 13 & 4 & 4 \\
\hline 11 & $\begin{array}{l}\text { Existence of equipments and urban } \\
\text { infrastructure services }\end{array}$ & 3 & 4 & 10 & 7 & 6 & 11 & $\begin{array}{l}\text { Lack of appropriate spaces for area s } \\
\text { Residents need for their free time }\end{array}$ & 3 & 4 & 10 & 7 & 6 \\
\hline 12 & $\begin{array}{l}\text { Emergency availability of cavalry } \\
\text { in old area }\end{array}$ & 2 & 2 & 9 & 14 & 3 & 12 & Surface water disposal problem & 2 & 2 & 9 & 14 & 3 \\
\hline 13 & $\begin{array}{l}\text { No need for residents to enter } \\
\text { Textures with their own car }\end{array}$ & 2 & 3 & 16 & 6 & 3 & 13 & $\begin{array}{l}\text { Improper installation of utilities Such as } \\
\text { beams and cables }\end{array}$ & 2 & 3 & 16 & 6 & 3 \\
\hline 14 & $\begin{array}{l}\text { High personal property Buildings in } \\
\text { the old tissue }\end{array}$ & 1 & 1 & 12 & 12 & 4 & 14 & $\begin{array}{l}\text { Low quality of floor, body And roof } \\
\text { facade and the lack of urban legibility }\end{array}$ & 1 & 1 & 12 & 12 & 4 \\
\hline 15 & $\begin{array}{l}\text { Expressed overwhelming desire } \\
\text { Residents for the repairing and } \\
\text { modernization Residential Units }\end{array}$ & 3 & 5 & 14 & 8 & 0 & 15 & $\begin{array}{l}\text { Traffic congestion on the streets } \\
\text { surrounding The district (create Vehicle } \\
\text { and pedestrian traffic) }\end{array}$ & 3 & 5 & 14 & 8 & 0 \\
\hline
\end{tabular}

Very high points: 5 high points: 4 middle points: 3 less points: 2 very low points: 1.

\subsection{Analysis of Ab-Anbr-No District's Worn-Out Texture}

SWOT technique is for analyzing the texture characteristics of the technique to identify the threats and opportunities in the external environment system, and to recognition its internal strengths and weaknesses in order to assess the situation and develop strategies for its control and guidance system [21]. Thus, according to the strengths and weaknesses and the opportunities and threats affecting the renovation and renovation of Ab-Anbar-No district's 
Table 2. The external factors of evaluation matrix.

\begin{tabular}{|c|c|c|c|c|c|c|c|c|c|c|c|c|c|}
\hline \multirow{2}{*}{ ఇָ } & \multirow[b]{2}{*}{ Opportunities } & \multicolumn{5}{|c|}{ Frequency } & \multirow{2}{*}{ 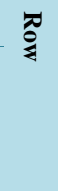 } & \multirow[b]{2}{*}{ Threats } & \multicolumn{5}{|c|}{ Frequency } \\
\hline & & $\frac{\substack{\frac{3}{2} \\
\frac{0}{2}}}{2}$ & 官 & 高 & 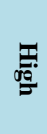 & 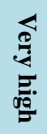 & & & 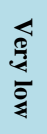 & $\sum_{\xi}^{5}$ & 高 & 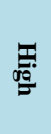 & 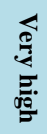 \\
\hline 1 & $\begin{array}{l}\text { There are suitable Economic, social and } \\
\text { cultural applications and condition near } \\
\text { The texture adjacent Qarn and farhang } \\
\text { street to attract tourism to texture }\end{array}$ & 0 & 1 & 10 & 14 & 5 & 1 & $\begin{array}{l}\text { Reduced tendency to settle in Cultural and } \\
\text { historical texture and on the other hand } \\
\text { low-income people immigration Including } \\
\text { villagers to the texture }\end{array}$ & 1 & 2 & 7 & 12 & 8 \\
\hline 2 & $\begin{array}{l}\text { Closing urban elements to a.a.n district } \\
\text { such mosque, bazaar and saat quarter to } \\
\text { practical promotion for absorbing tourists. }\end{array}$ & 0 & 0 & 6 & 19 & 5 & 2 & $\begin{array}{l}\text { Reduction of texture security because of } \\
\text { The criminals and addicts traffic to the } \\
\text { texture }\end{array}$ & 1 & 3 & 7 & 8 & 11 \\
\hline 3 & $\begin{array}{l}\text { Rural vendors Daily migration to } \\
\text { downtown and create Dynamics in the } \\
\text { center and mobility of Official-Commercial } \\
\text { Activities Near the historic urban fabric }\end{array}$ & 1 & 2 & 12 & 13 & 2 & 3 & $\begin{array}{l}\text { The increase of rental settlements by } \\
\text { migrants }\end{array}$ & 0 & 3 & 9 & 15 & 3 \\
\hline 4 & $\begin{array}{l}\text { Existence of investment fields to providing } \\
\text { urban services (Cultural, recreation, } \\
\text { housing, public parking) }\end{array}$ & 1 & 2 & 12 & 14 & 1 & 4 & $\begin{array}{l}\text { Lack of attention to historical background } \\
\text { of district in Modernize it }\end{array}$ & 0 & 1 & 5 & 15 & 3 \\
\hline 5 & $\begin{array}{l}\text { Development of outdoor and greenbelt } \\
\text { spaces utilizing opportunities (padegan-baq } \\
\text { roshan area) }\end{array}$ & 0 & 2 & 9 & 16 & 3 & 5 & $\begin{array}{l}\text { Lack of incentives for Private investment } \\
\text { in restoration of buildings }\end{array}$ & 1 & 1 & 5 & 12 & 11 \\
\hline 6 & $\begin{array}{l}\text { Existence of relative adopting of historical } \\
\text { city construction and nowadays city }\end{array}$ & 0 & 6 & 15 & 8 & 1 & 6 & $\begin{array}{l}\text { Positioning and expansion Incongruent } \\
\text { commercial, office and... units In texture }\end{array}$ & 1 & 3 & 8 & 14 & 4 \\
\hline 7 & $\begin{array}{l}\text { Improving the city's mainlines (urban } \\
\text { bodies of pavements and night lighting) }\end{array}$ & 1 & 2 & 8 & 14 & 5 & 7 & $\begin{array}{l}\text { Without coordination and non-targeted } \\
\text { destruction of texture }\end{array}$ & 1 & 0 & 5 & 12 & 12 \\
\hline 8 & $\begin{array}{l}\text { Existence of green spaces and private and } \\
\text { public gardens of baq roshan, the ambit in } \\
\text { front of governorship building }\end{array}$ & 1 & 1 & 17 & 9 & 2 & 8 & $\begin{array}{l}\text { Structures building, particularly } \\
\text { Non-native viewing of buildings On the } \\
\text { edge of the main arteries }\end{array}$ & 2 & 1 & 4 & 10 & 13 \\
\hline 9 & $\begin{array}{l}\text { Providing limited number of public parking } \\
\text { for district residents surrounding qarn street }\end{array}$ & 1 & 2 & 11 & 10 & 6 & 9 & $\begin{array}{l}\text { Renovating of worn-out textures to absorb } \\
\text { tourists }\end{array}$ & 1 & 3 & 19 & 2 & 5 \\
\hline 10 & $\begin{array}{l}\text { The use of Groundwater resources for } \\
\text { development green space. }\end{array}$ & 1 & 4 & 13 & 7 & 5 & 10 & $\begin{array}{l}\text { The lack of coherent and Hierarchy } \\
\text { structure in program Planning }\end{array}$ & 1 & 0 & 9 & 7 & 12 \\
\hline 11 & $\begin{array}{l}\text { Paying attention to this Historical Center } \\
\text { and try to Revenues and Correcting } \\
\text { problems }\end{array}$ & 1 & 2 & 5 & 11 & 11 & 11 & $\begin{array}{l}\text { An increase in traffic in the City center } \\
\text { because of enhancement of the } \\
\text { Non-residential users and population High } \\
\text { density }\end{array}$ & 0 & 1 & 6 & 11 & 12 \\
\hline 12 & $\begin{array}{l}\text { Existence of an approved project from Top } \\
\text { officials }\end{array}$ & 1 & 0 & 5 & 18 & 6 & 12 & $\begin{array}{l}\text { The gradual loss of Organic face by } \\
\text { increasing widening of Historical texture } \\
\text { passages because of Easier entry cars }\end{array}$ & 0 & 2 & 4 & 14 & 10 \\
\hline
\end{tabular}

Very high points: 5 high points: 4 middle points: 3 less points: 2 very low points: 1 .

worn-out texture, SWOT matrix is drawn on Table 3.

As shown on Table 3 in the studied area was identified 15 internal strength versus 15 internal weaknesses and also 12 external opportunities versus to 12 external threats and were considered in relation to the area. Thus, 27 strengths and opportunities are identified as an advantage, and 27 weaknesses are identified as a disadvantage for renovation and rehabilitation constraints, appropriate and realistic strategies can be used to remove weaknesses and threats in the region and use of the strengths and opportunities of development to take advantage.

\section{Prioritization of SWOT Factors}

SWOT has not possibility of a comprehensive assessment at decision-making situation and just Prioritization a number of factors in the strengths, weakness, opportunities and threats group's, and thereby can identify the most important factors determining the importance of tools or assessment of decision options shall be provided 
Table 3. The SWOT skeletal, social-economic, management matris for Sari’s Ab-Anbar-No.

\begin{tabular}{|c|c|c|c|c|c|c|c|}
\hline \multicolumn{4}{|c|}{ Internal Factors } & \multicolumn{4}{|c|}{ External Factors } \\
\hline & Strengths & & Weaknesses & & Opportunities & & Threats \\
\hline 1 & $\begin{array}{l}\text { Residence in the district and } \\
\text { not being abandoned the old } \\
\text { texture }\end{array}$ & 1 & $\begin{array}{l}\text { Poor performance of Social, } \\
\text { economic and housing In the } \\
\text { district (is not vitality texture ) }\end{array}$ & 1 & $\begin{array}{l}\text { There are suitable Economic, } \\
\text { social and cultural applications } \\
\text { and condition near The texture } \\
\text { adjacent Qaran and Farhang } \\
\text { street to attract tourism to } \\
\text { texture }\end{array}$ & 1 & $\begin{array}{l}\text { Reduced tendency to settle in } \\
\text { Cultural and historical texture } \\
\text { and on the other hand } \\
\text { low-income people } \\
\text { immigration Including } \\
\text { villagers to the texture }\end{array}$ \\
\hline 2 & $\begin{array}{l}\text { Long living background of } \\
\text { some families with high social } \\
\text { status and neighborhood } \\
\text { communication }\end{array}$ & 2 & $\begin{array}{l}\text { Residents tend to aggregate Parts } \\
\text { and urbanization }\end{array}$ & 2 & $\begin{array}{l}\text { Closing urban elements to } \\
\text { Ab-anbar-no district such } \\
\text { mosque, bazaar and sa'at } \\
\text { quarter to practical promotion } \\
\text { for absorbing tourists. }\end{array}$ & 2 & $\begin{array}{l}\text { Reduction of texture security } \\
\text { because of The criminals and } \\
\text { addicts traffic to the texture }\end{array}$ \\
\hline 3 & $\begin{array}{l}\text { Traditional structure of district } \\
\text { and credit Elders to residents }\end{array}$ & 3 & $\begin{array}{l}\text { Reducing the rate of population } \\
\text { in the texture in compared total } \\
\text { city's population }\end{array}$ & 3 & $\begin{array}{c}\text { Rural vendors Daily migration } \\
\text { to downtown and create } \\
\text { Dynamics in the center and } \\
\text { mobility of } \\
\text { Official-Commercial Activities } \\
\text { Near the historic urban fabric }\end{array}$ & 3 & $\begin{array}{l}\text { The increase of rental } \\
\text { settlements by migrants }\end{array}$ \\
\hline 4 & $\begin{array}{l}\text { The high price of land in the } \\
\text { tissue(Investment incentives. } \\
\text { is } 30 \% \text { for rental and the rest } \\
\text { are landlord) }\end{array}$ & 4 & $\begin{array}{c}\text { Lack of proper cultural places on } \\
\text { district }\end{array}$ & 4 & $\begin{array}{l}\text { Existence of investment fields } \\
\text { to providing urban } \\
\text { services (Cultural, recreation, } \\
\text { housing, public parking) }\end{array}$ & 4 & $\begin{array}{c}\text { Lack of attention to historical } \\
\text { background of district in } \\
\text { Modernize it }\end{array}$ \\
\hline 5 & $\begin{array}{l}\text { Existence of commercial and } \\
\text { administrative units On } \\
\text { surrounding streets, Residence } \\
\text { supportive }\end{array}$ & 5 & $\begin{array}{c}\text { Decreasing security because of } \\
\text { lack of lighting particularly at } \\
\text { nights }\end{array}$ & 5 & $\begin{array}{c}\text { Development of outdoor and } \\
\text { greenbelt spaces utilizing } \\
\text { opportunities (padegan-baq } \\
\text { roshan area) }\end{array}$ & 5 & $\begin{array}{c}\text { Lack of incentives for Private } \\
\text { investment in restoration of } \\
\text { buildings }\end{array}$ \\
\hline 6 & $\begin{array}{l}\text { Meet the needs of area } \\
\text { residents through The glazed } \\
\text { area (because of Closing to } \\
\text { downtown) }\end{array}$ & 6 & $\begin{array}{l}\text { Defect of proper activity } \\
\text { concerning tourism }\end{array}$ & 6 & $\begin{array}{c}\text { Existence of relative adopting } \\
\text { of historical city construction } \\
\text { and nowadays city }\end{array}$ & 6 & $\begin{array}{l}\text { Positioning and expansion } \\
\text { Incongruent commercial, } \\
\text { office and... units In texture }\end{array}$ \\
\hline 7 & $\begin{array}{l}\text { Existence of valuable } \\
\text { architecture buildings }\end{array}$ & 7 & $\begin{array}{l}\text { The relative stagnation of } \\
\text { business activity in Some parts of } \\
\text { the tissue }\end{array}$ & 7 & $\begin{array}{l}\text { Improving the city's } \\
\text { mainlines(urban bodies of } \\
\text { pavements and night lighting) }\end{array}$ & 7 & $\begin{array}{l}\text { Without coordination and } \\
\text { non-targeted destruction of } \\
\text { texture }\end{array}$ \\
\hline 8 & $\begin{array}{l}\text { Location of the district on } \\
\text { historical texture and } \\
\text { downtown (closing district to } \\
\text { masjed jaame, bazaar and saat } \\
\text { squar) }\end{array}$ & 8 & $\begin{array}{l}\text { Lack of arrangement between old } \\
\text { buildings face and news one }\end{array}$ & 8 & $\begin{array}{l}\text { Existence of green spaces and } \\
\text { private and public gardens of } \\
\text { baq roshan, the ambit in front } \\
\text { of governorship building }\end{array}$ & 8 & $\begin{array}{l}\text { Structures building, } \\
\text { particularly Non-native } \\
\text { viewing of buildings On the } \\
\text { edge of the main arteries }\end{array}$ \\
\hline 9 & $\begin{array}{l}\text { Functional value as religious, } \\
\text { cultural center, because of } \\
\text { Hasina and bazaar and } \\
\text { business centers on texture }\end{array}$ & 9 & $\begin{array}{c}\text { Difficulty of renovation and } \\
\text { building activity because of } \\
\text { meandrous alleys }\end{array}$ & 9 & $\begin{array}{l}\text { Providing limited number of } \\
\text { public parking for district } \\
\text { residents surrounding qarn } \\
\text { street }\end{array}$ & 9 & $\begin{array}{l}\text { Renovating of worn-out } \\
\text { textures to absorb tourists }\end{array}$ \\
\hline 10 & $\begin{array}{c}\text { Existence of cullis for } \\
\text { gathering Surface water in } \\
\text { some passages }\end{array}$ & 10 & $\begin{array}{l}\text { Lack of cultural complexes, Art } \\
\text { centers and libraries public } \\
\text { centers, conference and Theater } \\
\text { halls, cultural institutions and } \\
\text { Etc. }\end{array}$ & 10 & $\begin{array}{l}\text { The use of Groundwater } \\
\text { resources for development } \\
\text { green space. }\end{array}$ & 10 & $\begin{array}{c}\text { The lack of coherent and } \\
\text { Hierarchy structure in program } \\
\text { Planning }\end{array}$ \\
\hline 11 & $\begin{array}{l}\text { Existence of equipments and } \\
\text { urban infrastructure services }\end{array}$ & 11 & $\begin{array}{l}\text { Lack of appropriate spaces for } \\
\text { area s Residents need for their } \\
\text { free time }\end{array}$ & 11 & $\begin{array}{c}\text { Paying attention to this } \\
\text { Historical Center and try to } \\
\text { Revenues and Correcting } \\
\text { problems }\end{array}$ & 11 & $\begin{array}{l}\text { An increase in traffic in the } \\
\text { City center because of } \\
\text { enhancement of the } \\
\text { Non-residential users and } \\
\text { population High density }\end{array}$ \\
\hline 12 & $\begin{array}{l}\text { Emergency availability of } \\
\text { cavalry in old area }\end{array}$ & 12 & Surface water disposal problem & 12 & $\begin{array}{l}\text { Existence of an approved } \\
\text { project from Top officials }\end{array}$ & 12 & $\begin{array}{l}\text { The gradual loss of Organic } \\
\text { face by increasing widening of } \\
\text { Historical texture passages } \\
\text { because of Easier entry cars }\end{array}$ \\
\hline 13 & $\begin{array}{l}\text { No need for residents to enter } \\
\text { Textures with their own car }\end{array}$ & 13 & $\begin{array}{l}\text { Improper installation of utilities } \\
\text { Such as beams and cables }\end{array}$ & & & & \\
\hline 14 & $\begin{array}{l}\text { High personal property } \\
\text { Buildings in the old tissue }\end{array}$ & 14 & $\begin{array}{l}\text { Low quality of floor, body And } \\
\text { roof facade and the lack of urban } \\
\text { legibility }\end{array}$ & & & & \\
\hline 15 & $\begin{array}{l}\text { Expressed overwhelming } \\
\text { desire Residents for the } \\
\text { repairing and modernization } \\
\text { Residential Units }\end{array}$ & 15 & $\begin{array}{l}\text { Traffic congestion on the streets } \\
\text { surrounding The district (create } \\
\text { Vehicle and pedestrian traffic) }\end{array}$ & & & & \\
\hline
\end{tabular}


in accordance with factors [22]. The plan mainly includes a large number of standards and their interdependence, it is possible to use the SWOT is not enough. According to the defect analysis SWOT, in order to increase its efficiency, some techniques combined with SWOT [19]. In this study, SWOT factors have been considered by participation of officials and experts on the five options on Likert scale. This scale is compound. Options in this scale determine their importance. Likert scale has been calculated for each factor to measuring the priority and ranking of internal and external environment SWOT factors, and formulas relative weight between the groups.

Formula $1 R_{i j}=\Sigma S_{i} \cdot F_{i} R_{i j}$ : Points of $\mathrm{j}$ from group $i$ (score) $S_{i}$ : Points range of Likert.

$F_{i}$ : Frequency choices.

Formula $2 Y_{i j}=\frac{R_{i j}}{\Sigma R_{i j}} Y_{i j}$ : Points of $\mathrm{j}$ from group $i$ (weight).

This formula, is one of the methods used to quantify SWOT and provide assessment possibility the relative importance of each groups factors and enable of each and principally assessment of decision-making situation will be combined with SWOT. So SWOT factors set have been designed in the questionnaire form in order to be weighted and prioritized by officials and experts of studied area.

Measurement and classify scale for each of these factors is that for every factor, there is a limitation from 1 to 5 set that number 1 means very low importance, number 2 means low important, the number 3 means average importance, the number 4 means the most important, and number 5 means extremely important factor in the renovation and modernization of the sari's A.A.N district's worn-out texture. then gained data's and information's have been analyzed and calculated based on total gained weights, mean rank, and their relative weights and have been applied in QUADRUPLET groups to ranking that they are mentioned in above table. So after weighing the four SWOT factors, now the ranking and priority analysis of strengths, weaknesses, opportunities and threats are discussed from the perspective of experts and officials, see Table 4 and Table 5.

Table 4. Ranking the prioritize of strengths and weaknesses from the approach of experts and officials.

\begin{tabular}{|c|c|c|c|c|c|c|c|c|c|c|c|}
\hline 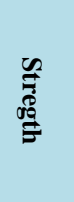 & 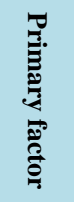 & 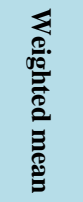 & 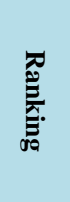 & 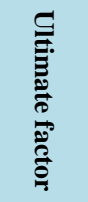 & 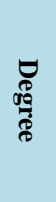 & 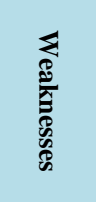 & 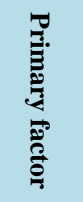 & 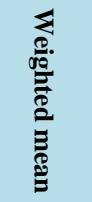 & 冚 & 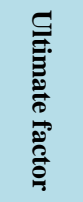 & 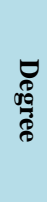 \\
\hline $\mathrm{S} 1$ & 108 & 0.065 & 3.2 & 0.208 & 10 & W1 & 101 & 0.059 & 3.2 & 0.188 & 14 \\
\hline $\mathrm{S} 2$ & 116 & 0.07 & 4.2 & 0.294 & 5 & W2 & 109 & 0.064 & 4.2 & 0.268 & 3 \\
\hline S3 & 122 & 0.074 & 4 & 0.296 & 4 & W3 & 96 & 0.056 & 3.4 & 0.19 & 13 \\
\hline $\mathrm{S} 4$ & 99 & 0.06 & 3 & 0.18 & 12 & W4 & 109 & 0.064 & 3.2 & 0.204 & 12 \\
\hline S5 & 103 & 0.062 & 3.2 & 0.198 & 11 & W5 & 115 & 0.068 & 3.4 & 0.231 & 7 \\
\hline S6 & 105 & 0.064 & 3.4 & 0.217 & 8 & W6 & 129 & 0.076 & 3.8 & 0.288 & 2 \\
\hline S7 & 125 & 0.076 & 4 & 0.304 & 3 & W7 & 99 & 0.058 & 3.2 & 0.185 & 15 \\
\hline S8 & 134 & 0.081 & 4.4 & 0.356 & 1 & W8 & 128 & 0.075 & 4.2 & 0.315 & 1 \\
\hline S9 & 123 & 0.075 & 3.6 & 0.27 & 6 & W9 & 108 & 0.064 & 3.6 & 0.23 & 9 \\
\hline $\mathrm{S} 10$ & 89 & 0.054 & 3 & 0.162 & 15 & W10 & 109 & 0.064 & 3.6 & 0.23 & 8 \\
\hline $\mathrm{S} 11$ & 98 & 0.059 & 3 & 0.177 & 13 & W11 & 116 & 0.068 & 3.6 & 0.244 & 6 \\
\hline $\mathrm{S} 12$ & 104 & 0.063 & 3.4 & 0.214 & 9 & W12 & 115 & 0.068 & 3 & 0.204 & 11 \\
\hline $\mathrm{S} 13$ & 91 & 0.055 & 3 & 0.165 & 14 & W13 & 113 & 0.067 & 3.2 & 0.214 & 10 \\
\hline $\mathrm{S} 14$ & 107 & 0.065 & 3.4 & 0.221 & 7 & W14 & 119 & 0.078 & 3.2 & 0.249 & 5 \\
\hline $\mathrm{S} 15$ & 116 & 0.077 & 4 & 0.308 & 2 & W15 & 120 & 0.071 & 3.8 & 0.269 & 4 \\
\hline Total & 1640 & 1 & 52.8 & 3.57 & & T1otal & 1686 & 1 & 52.6 & 3.509 & \\
\hline
\end{tabular}


Table 5. Ranking the prioritize of opportunities and threats from the approach of experts and officials.

\begin{tabular}{|c|c|c|c|c|c|c|c|c|c|c|c|}
\hline 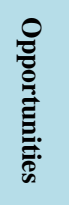 & 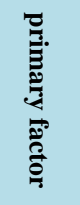 & 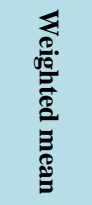 & 冚 & 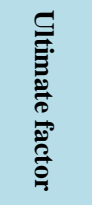 & 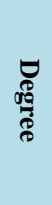 & $\begin{array}{l}\text { 쿨 } \\
\text { 蛋 }\end{array}$ & 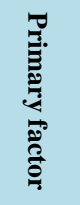 & 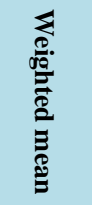 & 冚 & 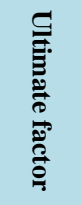 & 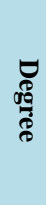 \\
\hline $\mathrm{O} 1$ & 113 & 0.087 & 4 & 0.348 & 4 & $\mathrm{~T} 1$ & 114 & 0.087 & 3.6 & 0.313 & 8 \\
\hline $\mathrm{O} 2$ & 117 & 0.09 & 4 & 0.36 & 3 & $\mathrm{~T} 2$ & 115 & 0.082 & 4 & 0.328 & 7 \\
\hline $\mathrm{O} 3$ & 102 & 0.078 & 3.8 & 0.296 & 6 & T3 & 108 & 0.077 & 3.6 & 0.277 & 11 \\
\hline $\mathrm{O} 4$ & 101 & 0.078 & 3.4 & 0.265 & 11 & $\mathrm{~T} 4$ & 125 & 0.089 & 3.4 & 0.302 & 10 \\
\hline O5 & 109 & 0.084 & 3.4 & 0.285 & 7 & $\mathrm{~T} 5$ & 121 & 0.086 & 4.2 & 0.361 & 4 \\
\hline O6 & 93 & 0.071 & 2.8 & 0.198 & 12 & $\mathrm{~T} 6$ & 107 & 0.076 & 4 & 0.304 & 9 \\
\hline $\mathrm{O} 7$ & 109 & 0.084 & 3.4 & 0.285 & 8 & $\mathrm{~T} 7$ & 124 & 0.088 & 4 & 0.352 & 5 \\
\hline O8 & 104 & 0.085 & 3.2 & 0.272 & 10 & $\mathrm{~T} 8$ & 121 & 0.086 & 4.2 & 0.361 & 3 \\
\hline O9 & 108 & 0.083 & 3.6 & 0.298 & 5 & T9 & 97 & 0.069 & 3.4 & 0.234 & 12 \\
\hline $\mathrm{O} 10$ & 101 & 0.078 & 3.6 & 0.28 & 9 & $\mathrm{~T} 10$ & 119 & 0.085 & 4.4 & 0.374 & 2 \\
\hline O11 & 119 & 0.091 & 4.4 & 0.4 & 1 & $\mathrm{~T} 11$ & 124 & 0.088 & 4.4 & 0.387 & 1 \\
\hline O12 & 118 & 0.091 & 4 & 0.364 & 2 & $\mathrm{~T} 12$ & 122 & 0.087 & 4 & 0.348 & 6 \\
\hline total & 1294 & 1 & 43.6 & 3.651 & & total & 1397 & 1 & 47.2 & 3.941 & \\
\hline
\end{tabular}

The results of this study to prioritize the strengths, weaknesses, opportunities and threats, as well as experts and officials assessment of the SWOT method in the relative weight shows that the opportunity, have the most facilitates their involvement in the texture, because of the officials attention to this historic center and attempting to reformation and refining it (with a relative weight of 0.4 ) is. then, after it, the highest involvement is because of increase the traffic ratio in the downtown because of the increase in non-residential using with high population density (relative weight 0.387 ) and the lack of a coherent and hierarchical structure of the planning (relative weight 0.374 ) and this is one of threat of a Ab-Anbar-No in the renovation and rehabilitation of. Finally, prioritization the modernization and renovation of worn-out texture of Ab-Anbar-No district in Sari will be considered in Table 6.

\section{Chart Analysis of Strategic Factors Assessment Matrix}

As a result of internal and external strategic factors matrix Ab-Anbar-No district in Sari shows, the weaknesses and opportunities for Sari renovation and modernization are almost identical. And threats are predominant on Opportunities. And the internal factors matrix has a better situation compared to external factors matrix. According to the findings of this study sari's worn-out texture strategies diversification strategy (contingent) that in such a situation we should try to adopt appropriate mechanisms to implement strategies to use with ST own internal strengths to avoid the negative effect of external threats to the city, see Table 7 and Figure 1.

Strategies matrix based on a comparison of internal factors (strengths and weaknesses) and external factors (opportunities and threats) that is included environmental situation in the Sari city in four types of strategies: A: offensive strategies (so). B: conservative strategy (ST). C: competitive strategies (wo). D: defensive strategies (WT) plotted and strategies have been provided. Detailed on Table 8.

\section{Discussion}

The preliminary results of hypothesis assessment of this study showed that renovation and rehabilitation to revive and create vitality of the worn-out Texture of Ab-Anbar-No district in Sari are approximately successful. In this analysis, the most important subjects that were seen as strength points in these projects is position of district on the historical texture and downtown (near the mosque, the bazaar and Sa'at quarter) and existence of 
Table 6. Prioritization the modernization and renovation of worn-out texture of Ab-Anbar-No district in Sari.

\begin{tabular}{|c|c|c|c|}
\hline Row & Factors & Relative weight & Factor cod \\
\hline 1 & Paying attention to this Historical Center and try to Revenues and Correcting problems & 0.4 & $\mathrm{O} 11$ \\
\hline 2 & $\begin{array}{c}\text { An increase in traffic in the City center because of enhancement of the Non-residential users } \\
\text { and population High density }\end{array}$ & 0.387 & T11 \\
\hline 3 & The lack of coherent and Hierarchy structure in program Planning & 0.374 & T10 \\
\hline 4 & Existence of an approved project from Top officials & 0.364 & $\mathrm{O} 12$ \\
\hline 5 & $\begin{array}{l}\text { Structures building, particularly Non-native viewing of buildings On the edge of the main } \\
\text { arteries }\end{array}$ & 0.361 & T8 \\
\hline 6 & Lack of incentives for Private investment in restoration of buildings & 0.361 & T5 \\
\hline 7 & $\begin{array}{l}\text { Closing urban elements to Ab-anbar-no district such mosque, bazaar and Sa'at quarter to } \\
\text { practical promotion for absorbing tourists. }\end{array}$ & 0.36 & $\mathrm{O} 2$ \\
\hline 8 & $\begin{array}{c}\text { Location of the district on historical texture and downtown (closing district to Masjed Jaame, } \\
\text { bazaar and Sa'at squar) }\end{array}$ & 0.356 & S8 \\
\hline 9 & Without coordination and non-targeted destruction of texture & 0.352 & $\mathrm{~T} 7$ \\
\hline 10 & $\begin{array}{l}\text { There are suitable Economic, social and cultural applications and condition near The texture } \\
\text { adjacent Qarn and Farhang street to attract tourism to texture }\end{array}$ & 0.348 & $\mathrm{O} 1$ \\
\hline 11 & $\begin{array}{c}\text { The gradual loss of Organic face by increasing widening of Historical texture passages } \\
\text { because of Easier entry cars }\end{array}$ & 0.348 & T12 \\
\hline 12 & Reduction of texture security because of The criminals and addicts traffic to the texture & 0.328 & $\mathrm{~T} 2$ \\
\hline 13 & Lack of arrangement between old buildings face and news one & 0.315 & w8 \\
\hline 14 & $\begin{array}{l}\text { Reduced tendency to settle in Cultural and historical texture and on the other hand } \\
\text { low-income people immigration Including villagers to the texture }\end{array}$ & 0.313 & $\mathrm{~T} 1$ \\
\hline 15 & $\begin{array}{c}\text { Expressed overwhelming desire Residents for the repairing and modernization Residential } \\
\text { Units }\end{array}$ & 0.308 & S15 \\
\hline 16 & Existence of valuable architecture buildings & 0.304 & S7 \\
\hline 17 & Positioning and expansion Incongruent commercial, office and... units In texture & 0.304 & T6 \\
\hline 18 & Lack of attention to historical background of district in Modernize it & 0.302 & $\mathrm{~T} 4$ \\
\hline 19 & Providing limited number of public parking for district residents surrounding qarn street & 0.298 & O9 \\
\hline 20 & Traditional structure of district and credit Elders to residents & 0.296 & S3 \\
\hline 21 & $\begin{array}{l}\text { Rural vendors daily migration to downtown and create dynamics in the center and mobility } \\
\text { of Official-Commercial Activities Near the historic urban fabric }\end{array}$ & 0.296 & $\mathrm{O} 3$ \\
\hline 22 & $\begin{array}{l}\text { Long living background of some families with high social status and neighborhood } \\
\text { communication }\end{array}$ & 0.294 & S2 \\
\hline 23 & Defect of proper activity concerning tourism & 0.288 & w6 \\
\hline 24 & Improving the city's mainlines (urban bodies of pavements and night lighting) & 0.285 & O7 \\
\hline 25 & $\begin{array}{l}\text { Development of outdoor and greenbelt spaces utilizing opportunities (padegan-baq roshan } \\
\text { area) }\end{array}$ & 0.285 & O5 \\
\hline 26 & The use of Groundwater resources for development green space. & 0.28 & $\mathrm{O} 10$ \\
\hline 27 & The increase of rental settlements by migrants & 0.277 & $\mathrm{~T} 3$ \\
\hline 28 & $\begin{array}{c}\text { Existence of green spaces and private and public gardens of baq roshan, the ambit in front of } \\
\text { governorship building }\end{array}$ & 0.272 & O8 \\
\hline 29 & $\begin{array}{l}\text { Functional value as religious, cultural center, because of Hasina and bazaar and business } \\
\text { centers on texture }\end{array}$ & 0.27 & S9 \\
\hline 30 & $\begin{array}{l}\text { Traffic congestion on the streets surrounding The district (create Vehicle and pedestrian } \\
\text { traffic) }\end{array}$ & 0.269 & w15 \\
\hline 31 & Residents tend to aggregate Parts and urbanization & 0.268 & w2 \\
\hline 32 & $\begin{array}{c}\begin{array}{c}\text { Existence of investment fields to providing urban services (Cultural, recreation, housing, } \\
\text { public parking) }\end{array}\end{array}$ & 0.265 & $\mathrm{O} 4$ \\
\hline
\end{tabular}




\begin{tabular}{|c|c|c|c|}
\hline \multicolumn{4}{|c|}{ Continued } \\
\hline 33 & Low quality of floor, body And roof facade and the lack of urban legibility & 0.249 & w14 \\
\hline 34 & Lack of appropriate spaces for area s Residents need for their free time & 0.244 & w11 \\
\hline 35 & Renovating of worn-out textures to absorb tourists & 0.234 & T9 \\
\hline 36 & Decreasing security because of lack of lighting particularly at nights & 0.231 & w5 \\
\hline 37 & $\begin{array}{l}\text { Lack of cultural complexes, Art centers and libraries public centers, conference and Theater } \\
\text { halls, cultural institutions and Etc. }\end{array}$ & 0.23 & w10 \\
\hline 38 & Difficulty of renovation and building activity because of meandrous alleys & 0.23 & W9 \\
\hline 39 & High personal property Buildings in the old tissue & 0.221 & S14 \\
\hline 40 & Meet the needs of area residents through The glazed area (because of Closing to downtown) & 0.217 & S6 \\
\hline 41 & Emergency availability of cavalry in old area & 0.214 & S12 \\
\hline 42 & Improper installation of utilities Such as beams and cables & 0.214 & w13 \\
\hline 43 & Residence in the district and not being abandoned the old texture & 0.208 & $\mathrm{~S} 1$ \\
\hline 44 & Surface water disposal problem & 0.204 & w12 \\
\hline 45 & Lack of proper cultural places on district & 0.204 & W4 \\
\hline 46 & $\begin{array}{c}\begin{array}{c}\text { Existence of commercial and administrative units On surrounding streets, Residence } \\
\text { supportive }\end{array}\end{array}$ & 0.198 & S5 \\
\hline 47 & Existence of relative adopting of historical city construction and nowadays city & 0.198 & O6 \\
\hline 48 & Reducing the rate of population in the texture in compared total city's population & 0.19 & w3 \\
\hline 49 & Poor performance of Social, economic and housing In the district (is not vitality texture) & 0.188 & w1 \\
\hline 50 & The relative stagnation of business activity in Some parts of the tissue & 0.185 & W7 \\
\hline 51 & $\begin{array}{c}\text { The high price of land in the tissue (Investment incentives. is } 30 \% \text { for rental and the rest are } \\
\text { landlord) }\end{array}$ & 0.18 & S4 \\
\hline 52 & Existence of equipments and urban infrastructure services & 0.177 & S11 \\
\hline 53 & No need for residents to enter Textures with their own car & 0.165 & S13 \\
\hline 54 & Existence of cullis for gathering Surface water in some passages & 0.162 & S10 \\
\hline
\end{tabular}

Table 7. Combination of internal and external factors worn-out texture of Ab-Anbar-No.

\begin{tabular}{cccccc}
\hline & Internal factors & & \multicolumn{2}{c}{ External factors } \\
\hline S & W & O & T \\
3.57 & 3.5 & 3.65 & 3.94 \\
\hline & & Total ratio of compound & & WO \\
\hline SO & WT & ST & 7.15 & \\
\hline 7.22 & 7.44 & 7.51 & \\
\hline
\end{tabular}

valuable architecture construction on the district after renovation and rehabilitation of mansion. The results of this research have the same direction with the acquisition results of numerous researches that considered the role of the revival and vitality of worn-out texture around the country. Hadavi and colleagues (2011) pointed in their article: it is preferred that the implementation of any project in the worn-out texture be quite conservative and based on the model of Conservation and Adaptation and Ravanbakhshi texture, because of the valuable elements [23].

In addition, Kayani and colleagues (1390) concluded in his research that identity and appearance expression of the city culture emphasize on save them with renovation and rehabilitation. The most important reasons of concerning historical texture are archaeological values and saving identity of place. The main reasons concerning the historical texture, is archaeological value and save the identity of place and identity of this part [24]. 


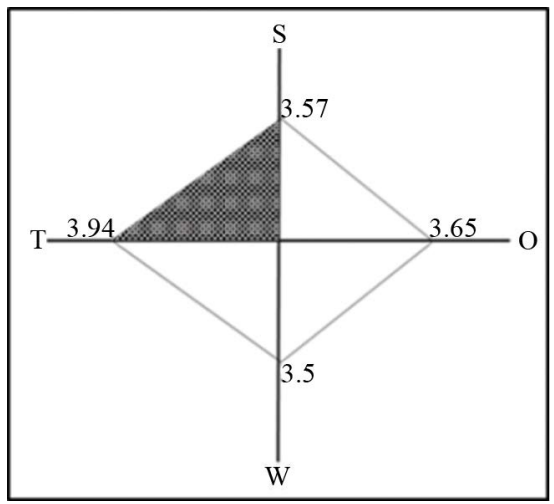

Figure 1. Evaluation of internal and external factors SWOT.

Table 8. Strategies of rehabilitation and renovation of Ab-Anbar No district in Sari.

\begin{tabular}{|c|c|}
\hline Offensive strategies (so) & competitive strategies (wo) \\
\hline $\begin{array}{l}\text { —Providing financing facilitates to development of residential } \\
\text { complexes } \\
\text { - Guidance and control renovation projects in historical context } \\
\text { on the basis of Their income } \\
\text { —-Participate in human resources providing }\end{array}$ & $\begin{array}{l}\text { —Urban design project definition and prioritization of intervention } \\
\text { - Help people living in these areas for the construction of the project } \\
\text { By themselves } \\
\text { —-Providing tax relief to old owners } \\
\text { —Approving the rules for participation and cooperation of banks } \\
\text { with institutions and Private companies for modernization and } \\
\text { change users }\end{array}$ \\
\hline conservative strategy (ST) & defensive strategies (WT) \\
\hline $\begin{array}{l}\text { - development of outdoor green space and in the area } \\
\text { —-Providing public parking on the sidelines and into the texture } \\
\text { —allocation of valuable historical passages for pedestrians } \\
\text { crossing streets } \\
\text { —-Preservation of monuments and valuable buildings) hoseinie, } \\
\text { Ab-Anbar-No ancient house (in the texture of destruction at } \\
\text { restoration the texture } \\
\text {-Providing services and infrastructural Installation to avoid } \\
\text { from old Residents exit. }\end{array}$ & $\begin{array}{l}\text { —Correcting and completing drainage system to collect and transport } \\
\text { water } \\
\text { In order to increase the power of crossing channels water } \\
\text { —Encouraging people to formation of local organizations } \\
\text { — rehabilitation and renovation based on residents opinion } \\
\text { — utilizing religious groups), religious commission, mosque trustees } \\
\text { and districts Trustees (for solidarity to reduce vulnerabilities and } \\
\text { diminish Threats }\end{array}$ \\
\hline
\end{tabular}

Motamedi Mehr and et al. (in 1393) emphasize to the evaluation of the physical improvement and enable texture functional, paying attention to the cultural heritage and value architectural monuments in the worn-out texture of cities [25].

In assessing the second hypothesis, it was found that the modernization and renovation for restore and revival the historic texture of Ab-Anbar-No district in Sari is faced with constraints and impasses. In the assessment of the weaknesses in the study, it was found that the lack of arrangement between old buildings facade and New buildings, low quality of floor facade, shell and roof, one of most important weaknesses is lack of arrangement of the city are in this article and many done researches about the vitality of historic fabric, have been proven that there is lack of appropriate activities related to tourism.

As results of Asadian and Sayyahi research (1390) the low quality of buildings, building materials, narrow streets and passages and lack of Ability to repair and improvement the texture of has been increased problems and they become demolished places [26]. Shamaei and Pourahmad (1383) are believed that one of the factors that led to the recession and sluggish the historical context, is indifference to the Structural repair, and single buildings repair and Lack of relevant extension work, including hull design or repair of streets face without paying attention to living conditions in this textures [27].

The low motivation of private sector for investment in connection with the restoration of the buildings is impressive. In multiple studies has been mentioned to this issue. Davoud Pour and Nick NIA (1390) expressed that the current transport system have created complex set of urban issues Such as air pollution, erosion, uncontrolled development and social isolation [28]. Mosayeb Zade and Abedini concluded in their article with this topic: “Analysis to determine optimal strategies for rehabilitation and renovation of worn-out texture” (1391) 
that some of the problems that most worn Texture face, such as the entry of vehicles from other parts of city for Parking and daily purchases, that cause depriving residents of cities' central area calmness, should be minimize with an Integrated and efficient planning to encourage residents investing and re-building the buildings [29]. Also, Tavakoli Nia and Mohammadi, (1389) concluded in their study that the improvement and renovation of the downtown texture is realistic through management policies and planning [30].

\section{Conclusions}

Worn-out texture, the cities and their identity should be maintained. Worn-out urban central area which is evolved according to social-economic condition and based on urban development patterns, nowadays is needy to codification strategies for renovation and modernization with an emphasis on public participation and government assistance, because of worn-out texture and low economic status of most residents. It is essential to improve the physical condition of such textures, several matters such residents economic, social, and cultural issues, which are surveyed and avoided from one-dimensional view (just physical view).

As regards, the facilities for getting a loan from domestic organizations, existence of Bazaar as the main economic subject of city and valuable places and historic monuments, worn-out texture of Ab-Anbar-No Sari have potentials for renovation and modernization, which can be achieved valuable results in organizing this district with concerning to strength points and opportunities, also with decreasing weaknesses and identified threats. Some of the problems that most worn-out textures in the Iran's central cities are faced with them, such as the entry of vehicles from other parts of city for parking and daily purchases, that cause depriving residents of cities' central area calmness, which should be minimized with an integrated and efficient planning to encourage residents investing and re-building the buildings.

\section{Suggested Solutions}

—Creating audio filters or planting trees in the adjacent crowded access such Enqelab and Qaran streets.

- Reducing pollution in main streets by increasing green spaces and greenbelts.

- Increasing green and outdoor spaces and good distribution in this district.

- Supplying and strengthening the activity and settlement combination.

-Distribution of complex applications to ensure the safety of public spaces.

-Emphasis to spaces around Takyes, Ab-Anbar-No and prepare them for situations such communications and ceremonies, feasts and celebrations.

-Develop various youth associations in the neighborhood.

-Codifying protection rules for districts' valuable buildings and environments.

- Infrastructure reform (flooring, bodies, green space, lighting).

- Creating a walking route with rules of urban planning at the Ab-Anbar-No alley.

- Improvements the pedestrian floor in the proposed walking lines.

- Use of local materials in construction such as ceramics, wood, etc

-Use of indigenous architectural elements in construction such as roof slope, Bal architecture, Saghanefar, porch and...

-Allocation of valuable passages and spaces to walking (like baazars' main street to Ab-Anbar-No).

—Provide public parking on the edge of the neighborhood (the main street Qaran, 18 dey, Farhang).

\section{References}

[1] Zangi Abadi, A. (2013) Spatial Analyze Pattern of Physical Development of the Kerman City. MSc Thesis, Tarbiat Modarres University.

[2] Habibi, P.K., Meshkini, A. and Abolfazl (2010) Renovation and Rehabilitation of Urban Old Texture. Vol. 2, Publication of Entekhab, Tehran.

[3] Sutcliffe, A. (1980) The Rise of Modern Urban Planning 1800-1914. Mansell, London.

[4] Planning and Architecture Supreme Council of Iran (2004) Decisions Definitions of the Council. the Council Secretariat, Tehran.

[5] Adams, D. and Hastings, E.M. (2001) Urban Renewal in Hong Kong: Transition from Development Corporation to Renewal Authority. Land Use Policy, 18, 245-258. http://dx.doi.org/10.1016/S0264-8377(01)00019-9

[6] Kalantary, K.A.H. and Pour A.A. (2005) Techniques and Experiences of Urban Restoration Planning. Publications of 
Institute for Higher Education, Tehran.

[7] Greg, A., Mohamed, E.H. and Horner, M. (2010) Using Deprivation Indices in Regeneration: Does the Response Match the Diagnosis? Cities, 27, 476-482. http://dx.doi.org/10.1016/j.cities.2010.01.005

[8] Mcdanald, S., Malys, N. and Maliene, V. (2009) Urban Regeneration for Sustainable Communities: A Case Study. Technological and Economic Development of Economy, 15, 49-59.

[9] Kamrava, M., et al. (2010) Research Project "Evaluation of Fifteen Years of Intervention in the Old Urban Textures of Iran” Renovation Organization of Tehran.Tehran University.

[10] The Hydalo Company (2014) Rehabilitation and Improvement of Ab-Anbar No District, Civil and Urban Improvement of Iran.

[11] Habibi, K., Pour Ahmad, A. and Meshkini, A. (2007) Renovation and Rehabilitation of Urban Old Textures. Vol. 1, Publication of Kordestan Univercity.

[12] Bryson John, M. (2002) Strategic Planning for Non-Governmental and Non-Profit Organizations, Translated by Abbas Monavarian, Publications of Management and Planning Organization, Center for Governmental Management Education, Tehran.

[13] Roberts, P. and Sykes, H. (2003) Urban Regenration, a Hand Book London.

[14] Consulting Engineers of Abardasht (2000) Projects of Renovation and Rehabilitation of Worn-Out Textures in Sari, Housing and Urban Development of Mazandaran.

[15] Mohammadi D., Cheshme, M. and Zangi Abadi, A. (2007) Feasibility Study of Ecotourism Potential of Chaharmahal Bakhtiari Eparchy, Using SWOT Method. The Environmental Magazine, 34, 1-10.

[16] Mousavi, A. (2014) The Role of Attractions and Tourist Potential on Attracting Tourists in Sepidan. Msc Thesis of Urban Plannig of Geographic, Univercity of Isfahan.

[17] Yuksel, I. and Divinen, M.D. (2007) Using the Analytic Network Process (ANP) in a SWOT Analysis-A Case Study for Textile Firm. Information Sciences, No, 177, 3364-3382.

[18] Hartman, F.T., Karahn, J. and Skulmoski, G.J. (2007) The Delphi Method for Graduate Research. Journal of Information Technology Education, 6, 1-21.

[19] Houben, C., Lenie, K. and Van Hoof, K. (1999) A Knowledge Based SWOT Analysis System as an in Strumpet for Strategic Planning in Small and Medium Sized Enterprises. Decision Support Systems, No. 26, 125-135.

[20] Roberts, P. and Sykes, H. (2000) Urban Regeneration. SAGE Publication, London.

[21] Moradi, M.V. (2005) Strategic Planning and Its Application on Urbanism in Iran. Publication of Urban Processing and Planning Company, 1.

[22] Dayson, R.G. (2004) Strategic Development and SWOT Analysis at the University of War Wick. European Journal of Operational Research, No. 52, 631-640.

[23] Hadavi, F., Ahad Nejad, M., Kalantari, K.A.H. and Rabiee, F.V. (2011) Strategies of Renovation of Old Historical Texture of Zanhan City Using the SWOT Technique. Journal of Geography and Planned Urban from Zagros Landscape, 4, 151-171.

[24] Kiani, A., Salari, S.F. and Afrasiabi, R.M. (2009) Evaluation of Making Identity of Firouz Abad City in Rehabilitation and Renovation of Worn-Out Texture of Shahre Gour Using Swot Method. Amayesh Geographic Journal, 6, 120-138.

[25] Motamedi, M.A., Hassan, P.R. and Rezaee, R. (2014) Renovation and Rehabilitation of Worn-Out Urban Texture with an Emphasis on Public Participation-Case Study: Qlyr Qorveh. Journal of Geographic View of Human Studies, 26, 29-44.

[26] Asadian, F. and Sayyahi, Z. (2011) The Role of Public Participation in the Rehabilitation and Renovation of Worn-Out Urban Texture Using Geographic Information Systems of Case Study: Ameri District in Ahvaz. Amayesh Journal, 4, 139-163.

[27] Shamaei, A. and Pourahmad, A. (2004) Analysis on Policies and Programs of Urban Rehabilitation and Renovation in Country Development Programs. Geological Research Journal, 48, 181-204.

[28] Davoudpour, Z. and Nick, N.M. (2011) Strategic Rehabilitation and Renovation of Urban Worn-Out Texture Towards Achieving the Physical Dimensions of Stable Urban Development-Case Study: Worn-Out Texture of Sajjadiyyah District. Amayesh Journal, 4, 31-59.

[29] Mosayyeb, Z.A. and Abedini, A. (2012) Analysis of Determine Optimal Strategies for Modernization and Rehabilitation of the Worn Out Texture. Case Study: The Central Part of the City of Uremia, 12, 100-115.

[30] Tavakoli, N.J. and Mohammadi, R. (2010) Physical Functional Erosion in the Central Texture of Cities Objectives and Guiding Principles to Improvement, Modernization and Reconstruction-Case Study: Central Texture of Zanjan, Publication. Earth Science Researches, 1, 35-54. 